\section{山形盆地立谷川扇状地の扇央部における地温の深度 分布}

\section{加 藤 武 雄}

最上川水系須川の支川立谷川は西方に向って扇状地 を展開し，その扇面では，従来から地下水が開発・利 用されている。その実態については, 1958 年に国土調 查法に基づく調査が実施され，その成果はすでに報告 された（経企庁・山形県, 1959)。その調査に関連して, われわれは扇央部の一観測井（山形刑務所敷地内）に ついて, 地下水温の深度分布を観測することがでさた。 この観測井は自噴せず，末た掘削後しばらく未使用の 状態にあったので，観測時に抢ける井内水温の分布は 自然状態を保持していたものとみられる。当日の自然 水位は $4.50 \mathrm{~m}$ で, 測温は深度 $45 \mathrm{~m}$ 采で可能であった。 な㧍，観測井のストレーナーは，深度 $31 \sim 37 \mathrm{~m}$ (a) と 39 46 m (b)の 2 個所に切られてある。観測結果は 図 1 に示さ机てあるが，こ机にはストレーナー付近に 限って，地下水の比導電率の測定値も図示することに した。つぎに，同図に併記したボーリング資料（柱状 図）(山形市，1960，p. 88）と対比しながら，水温に関 して 2,3 の考察を試みたい。柱状図に見られる斜線は 粘土, 点は砂, 小円は砂利, 大円は礫を表わすもの之 する。

この観測井に打计る各深度の井内水温は, 近似的に は,そのままそこの地温を示すものと考光られるから， 図 1 は地温の深度分布図と見なせる。図を見ると，井 内水温の深度による变動のようすは, $11 \mathrm{~m}$ 以深では傾 度を異にする8本の線分を連結したもので表わされ る。ところで, 地下深部から上方だけに向って熱の流 動があり，しか子定常状態を保持していれば，各地層 の地温の垂直分布は，その熱伝導率に応じて温度勾配 の異なる直線分布をなすものといわれる（福富ら， 1967)。このような条件が，観測井付近の地層について も許容できると仮定すれば，少くとも深度 $11 \mathrm{~m}$ 以深 では，上記の傾度の異なる各線分は，それぞれ異なる 地層の地温分布を表わすものと推定してよい。地表よ り深度 $11 \mathrm{~m}$ までの層は地表温度, したがって気温の 影響範囲と見られ, 最低地温 $\left(11.2^{\circ} \mathrm{C}\right)$ を示守深度 (11 13 m) はこの扇状地での恒温層に当るものと考 えられる。この考兄は，木内（1950）の報文によって も支持される。ちなみに, 深度 $11 \mathrm{~m}$ まではそれ以深と 異なり，水温の深度傾度はマイナスになっている。要 するにA層では, 上部に出てゆく熱量と上部より入る 熱量とが釣合っているものとみられる。図を見れば, 大局的には，柱状図の各地層は地温分布から分けた各 線分 $(\mathrm{A} \sim \mathrm{H})$ に対比できることが知られる。したがっ て，ここでは上の仮定は正しく，このことは，いい変 えれば，地下水温の垂直分布の上うすから地層の重な り具合が知られる結果になる。さきに，同種の試みを 馬見が崎扇状地において行なったことがあるが（加藤 ら，1968），このように立谷川扇状地においても確かめ ることができた。

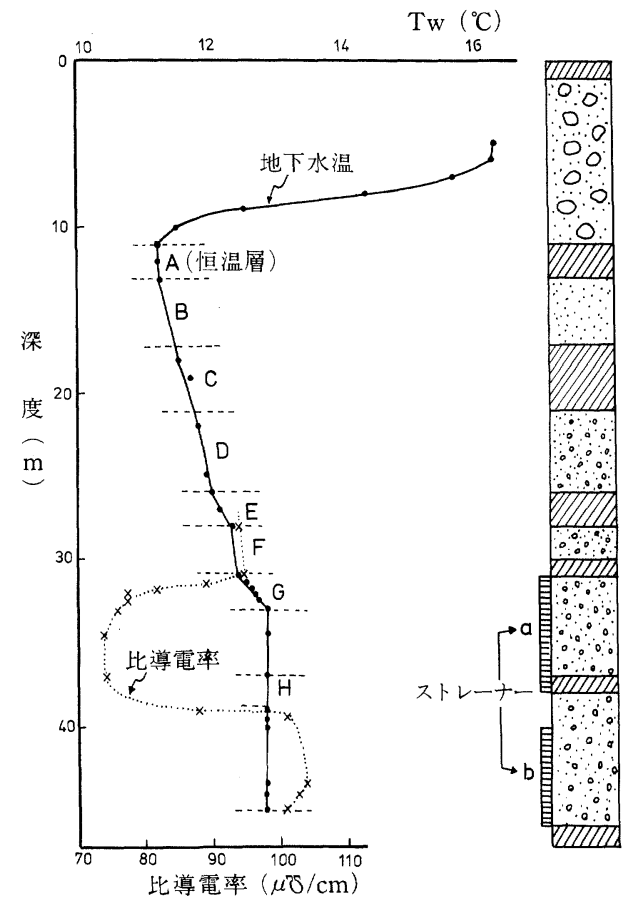

図 1 観測井内の地下水温の深度分布

1958 年 11 月 12 日 (午前 10 時) 観測, 気 温 $15.2^{\circ} \mathrm{C}$

最後に付記しておくが，ストレーナ一部分は有力な 帯水層を成すため，たえず湆水平方向に地下水が流 動し, この水塊の部分では全層を通じて水温が一定と なり，これより浅層部分へのひとつの熱供給源の役目 をなすものと考えられる。また比導電率を見ると， H 層は大きくいって水質の異なる二つの帯水層から成る こともわかる。

(1980年 3 月 18 日受理)

\section{文献}

福富孝治ら (1967)：山形県天童温泉の地球物理学的研 究 北大地球物理研究報告 $18 \quad 1 \sim 32$

加藤武雄・志田勇(1968)：山形市馬見が崎扇状地に 打ける 1 試錐井内の地温の垂直分布 東北地理 20 101

経済企画庁・山形県 (1959)：最上川水系立谷川・高瀬 川扇状地地下水調查報告書 48 頁

木内四郎兵衛 (1950): 土壤気象の研究 (恒温層深度之 温度に関する考察) 地学雑誌 $\quad 59 \quad 88 \sim 92$

山形市 (1960)：馬見崎川扇状地地下水調査報告書 (II) 94 頁

\title{
Vertical Distribution of Underground Temperature at a Boring Well in the Tachiya-gawa Alluvial Fan, Yamagata Basin, Northeast Japan
}

